\title{
Capital account liberalization and economic performance in Malaysia
}

\begin{abstract}
This study examines the impact of capital account liberalization on economic growth in Malaysia from 1970 to 2004. It uses two measures of capital account openness, namely de jure (an index of liberalization) and de facto (the volume of capital flows). The empirical results based on the modified growth model demonstrate that the de jure measure of capital account liberalization shows an adverse effect on growth in Malaysia. However, the de facto measure shows a robust positive effect on economic growth. The results also highlight that the effect of capital account liberalization on growth is contingent on a country's level of financial development and the quality of its institutions.
\end{abstract}

Keyword: Capital account openness; Economic growth; Institutions; Financial development; Bounds test 